\title{
Tree Allometry in Tropical Forest of Congo for Carbon Stocks Estimation in Above-Ground Biomass
}

\author{
Romeo Ekoungoulou1,2*, Xiaodong Liu'1, Jean Joël Loumeto², Suspense Averti Ifo ${ }^{2,3}$, \\ Yannick Enock Bocko², Fleury Edgard Koula², Shukui Niu' ${ }^{1}$ \\ ${ }^{1}$ Laboratory of Ecological Planning and Management, College of Forestry, Beijing Forestry University, Beijing, \\ China \\ ${ }^{2}$ Département de Biologie et Physiologie Végétales, Faculté des Sciences et Techniques, Université Marien \\ Ngouabi, Brazzaville, Republic of Congo \\ ${ }^{3}$ Département des Sciences Naturelles, Ecole Normale Supérieure, Université Marien Ngouabi, Brazzaville, \\ Republic of Congo \\ Email: ${ }^{*}$ romeoekous@gmail.com
}

Received 18 June 2014; revised 20 July 2014; accepted 12 August 2014

Copyright (C) 2014 by authors and Scientific Research Publishing Inc.

This work is licensed under the Creative Commons Attribution International License (CC BY).

http://creativecommons.org/licenses/by/4.0/

(c) (i) Open Access

\section{Abstract}

The research was aimed to estimate the carbon stocks of above-ground biomass (AGB) in Lesiolouna forest in Republic of Congo. The methodology of Allometric equations was used to measure the carbon stock of Lesio-louna tropical rainforest. The research was done with six circular plots each $40 \mathrm{~m}$ of diameter, with a distance of $100 \mathrm{~m}$ between each plot, depending on the topography of the site of the installation of these plots. The six studied plots are divided in two sites, which are: Iboubikro and Ngambali. Thus, in the six plots, there are three plots in Iboubikro site and three plots in Ngambali site. The results of this study show that the average carbon stock of aboveground biomass (AGB) in six plots was $170.673 \mathrm{t} \mathrm{C} \mathrm{ha}^{-1}$. So, the average of carbon stock of aboveground biomass (ABG) in Iboubikro site was $204.693 \mathrm{t} \mathrm{C} \mathrm{ha-1}^{-1}$ and in the Ngambali site was 136.652 t C ha-1. In this forest ecosystem, the high stock of carbon was obtained in Plot 3, which was in Iboubikro site. Plot 3 contains 20 trees and an average DBH of $24.56 \mathrm{~cm}$. However, the lowest carbon stock was obtained in Plot 4, which was in Ngambali site. Also, Plot 4 contains 11 trees and an average DBH of $31.86 \mathrm{~cm}$. The results of this research indicate that, the forests in the study area are an important carbon reservoir, and they can also play a key role in mitigation of climate change.

\section{Keywords}

Carbon Stock, Allometric Equations, Ngambali, Iboubikro, Above-Ground Biomass

\footnotetext{
${ }^{*}$ Corresponding author.
}

How to cite this paper: Ekoungoulou, R., Liu, X. D., Loumeto, J. J., Ifo, S. A., Bocko, Y. E., Koula, F. E., \& Niu, S. K. (2014). Tree Allometry in Tropical Forest of Congo for Carbon Stocks Estimation in Above-Ground Biomass. Open Journal of Forestry, 4, 481-491. http://dx.doi.org/10.4236/ojf.2014.45052 


\section{Introduction}

Tropical forests are a key component of the global carbon cycle (Djomo et al. 2010 and Ekoungoulou et al. 2014a). While the Congo basin is the second largest block of continuous tropical forest after the Amazonian basin, there is still a lot of uncertainty about the amount and spatial variations in above-ground biomass (biomass hereafter) and carbon stocks (Zhang et al. 2002 and FAO, 2011). The most voluminous greenhouse gas produced by humans is carbon dioxide $\left(\mathrm{CO}_{2}\right)$ as mentioned by Fayolle et al. (2013). In calculating overall carbon emissions, Kyoto Protocol allows certain removals of carbon by a nation's forests and soils carbon sinks to be counted and deducted from emissions (FAO, 2008). Thus, one option for mitigating greenhouse gas emissions and thus possible climate change is to increase the amount of carbon stored in forests (Gorte, 2009). Carbon sequestration, and the extent to which it can be counted as a reduction in a nation's carbon emissions, have been the focus of substantial controversy in international negotiations subsequent to the Kyoto Protocol (Gorte, 2009; Fayolle et al. 2013 and Holdaway et al. 2014). Global climate change is a widespread and growing concern that has led to extensive international discussions and negotiations (IPCC, 2001). One response to this concern have focused on reducing emissions of greenhouse gases, especially carbon dioxide (Brown et al. 2004), and on measuring carbon absorbed by and stored in forests, soils, and oceans. One option for slowing the rise of greenhouse gas concentrations in the atmosphere, and thus possible climate change, is to increase the amount of carbon removed by and stored in forests. Deforestation and forest degradation, located primarily in tropical regions, accounted for $12 \%$ - $20 \%$ of global anthropogenic greenhouse gas (GHG) emissions in the 1990s and early 2000s (IPCC, 2001). And these processes also impact the future potential of forests to remove additional carbon from the atmosphere (Gorte, 2009 and IPCC, 2011). Estimates of greenhouse gas emissions from deforestation require information on both the area of forest loss and the corresponding carbon stock of the land that is cleared (Chave et al. 2005 and Alvarez et al. 2012). Both are considered challenging to quantify accurately (Brown, 2002). Much of the emphasis to date has focused on improving spatially represented estimates of forest area loss (Brown et al. 2000 and FAO, 2008). To improve confidence in estimated emissions, equal emphasis is needed on improving spatially explicit estimates of carbon stored in forests, which remain uncertain in tropical regions. The largest proportion of this uncertainty is in estimates of aboveground biomass (Kearsley et al. 2013 and Ekoungoulou et al. 2014a), which accounts for 70\% - 90\% of forest biomass carbon (IPCC, 2001 and FAO, 2008), and its spatial variability that depends on factors such as climate, human and natural disturbance and recovery, soil type, and topographical variations (IPCC, 2011). Many techniques exist to estimate forest biomass at different spatial scales, but they all ultimately rely on ground and destructive measurements of individual tree biomass to calibrate allometric equations (Hall, 2012). An allometric equation is a statistical model relating tree biomass to a set of predictors such as tree diameter and/or height, wood specific gravity, or forest type (Chave et al. 2005 and Gorte, 2009). Allometric equations are used to convert forest inventory data into biomass estimates at tree-level, and the sum of all data for the trees allows a biomass estimate to be obtained at plot level (White et al. 1986; Chave et al. 2001 and Alvarez et al. 2012). Since existing allometric equations for tropical trees in African moist forests are restricted to a few specific species or sites (IPCC, 2001 and Djomo et al. 2010), pantropical multi-species equations are being used instead of estimating biomass from inventory data (Killeen et al. 2002; Lewis et al. 2009 and IPCC, 2011). Plot-based estimates of forest carbon stocks and carbon fluxes are derived metrics that contain multiple sources of uncertainty (Phillips et al. 1998; Malhi et al. 2004 and Chave et al. 2008). Calculations of forest carbon stock are usually based on plot-based field measurements of stem diameter and (occasionally) stem height. The imperfect measurements are transformed into stem biomass estimates, using models introducing model uncertainty (IPCC, 2001). These include height diameter models to predict tree height and carbon biomass models to predict carbon stock as a function of diameter, height and wood density (Yanai et al. 2010; Saatchi et al. 2011). Finally, biomass is summed across all stems in the plot and divided by the plot area to give total carbon stock estimated on a per-area basis. This step introduces a second element of measurement error relating to missing or double counted stems and the ability to accurately measure plot area in steep and undulating terrain (Brown et al. 2000 and Brown, 2002). In this study, we focused on above-ground woody biomass rather than on total above- and below-ground biomass. So, the aim of this study is to estimate the total carbon stock in Iboubikro and Ngambali forests (Lesio-louna area) in Republic of Congo. The results of this research will be useful by the Ministry of Sustainable Development, Forest Economy and Environment of Congo. 


\section{Materials and Methods}

\subsection{Study Area}

Study area is located at Lesio-louna $\left(14^{\circ} \mathrm{E}, 4^{\circ} \mathrm{S}\right), 140 \mathrm{~km}$ North East of Brazzaville in Teke Trays area (Republic of Congo) in Central Africa. Also, Lesio-louna is a wild life reserve that extends over approximately 173.000 ha. Teke Trays area wide range of trays starting from Republic of Gabon crossing Republic of Congo to the Democratic Republic of Congo. However, the average annual rainfall is $2100 \mathrm{~mm}$ (2008-2011) with a marked dry season from June to September and an annual average air temperature of $26^{\circ} \mathrm{C}$ (ANAC, 2014 and Ekoungoulou et al. 2014b). The climate of Lesio-louna is a tropical equatorial climate which is characterized by the absence of large dry seasons and low temperature differences (Makany, 1976 and Ekoungoulou et al. 2014a). Every month, there shall be at least $50 \mathrm{~mm}$ of water. There are two rainy seasons (March-May and October-December) and two dry seasons from June to August and from January to February. In Lesio-louna (study area), the average annual rainfall is around 1500 to $2000 \mathrm{~mm}$, but the plates is higher and reaches 2000 to $2500 \mathrm{~mm}$ (Makany, 1976 and ANAC, 2014). Savannas of Teke trays's South-eastern are wetter than the Southwest, which support only $1400-1800 \mathrm{~mm}$. This high rainfall zone extends to Gabon (Anon, 2010). Inter annual variability is important, however, as is common in regions near the equator (Ekoungoulou et al. 2014b).

\subsection{Data Collection}

We used diameter at breast height (DBH) and wood density for each tree in two sites of study area which are Iboubikro site and Ngambali site. Total number of plot in the study area was six (three plots in Iboubikro site and three plots in Ngambali site). Also, six plots are in gallery forest in Lesio-louna protect area. DBH of each tree was measured by using meter tape. The study was done with the circular plots for each site of study area. The size of each circular plot was $1256 \mathrm{~m}^{2}$. About the measurements of this study, the height of the chest was $1.30 \mathrm{~m}$ above the ground for each tree using meter tape. This study was done with the use of the compass to know the North, South, East and West positions. Measurements were made from the center of the plot to the North part, then from the center of the plot to the South part as mentioned by Pearson \& Brown, (2005). Following was from the center of plot to the East part, followed from the center of plot to the West part. This work was repeated in all six plots of our study area (Iboubikro and Ngambali sites) in Lesio-louna forest. Thus, we used the GPS to meet the GPS way point of each plot, about a precision of the geographical position of each plot and the entire study area. So, GPS way points were observed in the center of each plot and the compass was used as the center of each plot of this tropical rainforest. However, measuring of diameter at breast height of tree is important that the diameter at breast height's tape is properly used to ensure the consistency of measurements made. The following steps were respected:

- Make sure you have a bar or a pole with a length of $1.3 \mathrm{~m}$ to accurately measure line chest height on the tree (Pearson \& Brown, 2005; Ekoungoulou et al. 2014a). If there is none, using a large piece (2 cm of diameter) in better. In turn, each member of the survey team should measure itself on the location of the breast height is $1.3 \mathrm{~m}$ above the ground and rely on this site to determine where to put the meter tape;

- DBH tapes have a hook at the end. Push the hook into the bark of the tree and pull the tape to the right. DBH tape is always from the left and be pulled around the tree, even if the operator who takes action is a southpaw;

- When the tape is worn around the shaft and returns to the hook, the tape should be located above the hook. The tape should be upright and not upside down, the numbers must be in the correct reading order;

- If the tree is on a slope, always measure up the slope;

- If the shaft is tilted, the DBH tape should be worn according to the natural angle of the shaft, without taking into account the slope of the ground relative to the horizontal;

- If the tree has a fork at the chest level, take such action under the fork, and if that is not possible, consider that you are measuring two trees;

- If the tree is lying but still alive, then place the measuring stick down and measure at breast height as if the tree was standing. Trees are considered alive if they have green leaves;

- If a vine is growing on a tree to be measured, we do not cut the vine to clear a space to measure the diameter at breast height. If possible, move away from the vine trunk and drag the tape below. If the vine is too large to be removed from the trunk, we use the back of the ribbon and pull the front of the tree to assess the di- 
ameter of first hand. Cutting a vine should be the last option because in the long term with repeated measures taken, interfere with the natural dynamics of the plot eventually differentiate it from the surrounding forest. The same principle has to be respected for any other natural species found on a tree.

\subsection{Data Analysis}

We developed a set of local site-specific allometric equations. Following Chave et al. (2005), we fitted the following general allometric model to the observed data:

$$
\ln A G B=a+b * \ln (D)+C *(\ln (D) 2)+d *(\ln (D) 3)+\mathrm{e} * \ln (p)
$$

where above-ground biomass (AGB), D and $\rho$ are tree above-ground biomass (kg), diameter (in $\mathrm{cm}$ ) and wood specific gravity $\left(\mathrm{g} \cdot \mathrm{cm}^{-3}\right)$, respectively, and $a, b, c, d$, and e, the model parameters. Three alternative models were derived from model 1 . Model 2 was similar to model 1 but assumed that $\mathrm{e}=1$; model 3 assumed that $c=d=0$ and $\mathrm{e}=1$, and model 4 assumed that $c=d=\mathrm{e}=0$.

We then estimated the above-ground biomass $\left(A G B_{\text {est }}\right.$, in $\left.\mathrm{kg}\right)$ of each individual tree from the diameter $(\mathrm{D}$, in $\mathrm{cm}$ ) and wood specific gravity ( $\rho$ in $\mathrm{g} \cdot \mathrm{cm}^{-3}$ ) using the tropical equation developed by Chave et al. (2005) for moist forests (corresponding to forests with a marked dry season and between 1500 and $3500 \mathrm{~mm}$ annual rainfall), as follows:

$$
A G B=\rho * \operatorname{expo}\left(-1.239+1.980 \ln (D B H)+0.207(\ln (D B H))^{2}-0.0281\left(\ln (D B H) \ln (D B H)^{3}\right)\right.
$$

For unidentified species, we applied the mean wood density for each plot weighted, by the number of trees from each species (Ekoungoulou et al. 2014b).

Then, by Chave et al. (2005), for the rainforests, the general equation was chosen:

$$
A G B(\mathrm{~kg})=\rho * \exp (-1.239+1.980 \ln (D))+0.207(\ln (D))^{2}-0.0281(\ln (D))^{3}
$$

So, if the DBH one tree is $40.3 \mathrm{~cm}$. and his density is $\rho=0.05 \mathrm{~g} \cdot \mathrm{cm}^{-3}$. Then, $40.3 \mathrm{~cm}$ is well within the maximum diameter at breast height for this equation, which is reliable up to $148 \mathrm{~cm}$ as reported by Pearson \& Brown, (2005).

$$
\begin{gathered}
A G B(\mathrm{~kg})=\rho * \exp (-1.239+1.980 \ln (D))+0.207 \ln (D)^{2}-0.0281(\ln (D))^{3} \\
\rho=0.05 \mathrm{gcm}^{-3} \\
D=D B H=40.3 \mathrm{~cm} \\
A G B(\mathrm{~kg})=\rho * \exp \left(-1.239+1.980 \ln (D B H)+0.207\left(\ln (D B H)^{2}\right)-0.0281\left(\ln (D B H)^{3}\right)\right.
\end{gathered}
$$

The biomass of this tree is $211.5 \mathrm{~kg}$, or $0.2115 \mathrm{t}$. Then, to determine the carbon quantity of this tree, we divided the biomass obtained by two (Chave et al. 2005; Pearson \& Brown, 2005 and Ekoungoulou et al. 2014b). So, the carbon stock estimation of this tree is $0.1057 \mathrm{t} \mathrm{C}$.

\section{Results and Discussion}

In this research, two sites were studied with six plots (three plot each) in Republic of Congo. All six plots are in the gallery forest, precisely in Iboubikro forest and Ngambali forest. Figure 1 shows that, the average of carbon stock about above-ground biomass (AGB) was $204.693\left(\mathrm{t} \mathrm{C} \mathrm{ha}^{-1}\right)$ for Iboubikro forest and $136.6523333\left(\mathrm{t} \mathrm{C} \mathrm{ha}^{-1}\right)$ for Ngambali forest. In this forest, the high carbon stock was obtained in Plot 3, followed by plot 1, then plot 2 (Figure 2). The small quantity of carbon was stored in the Plot 4. Thus, there are three plots of Iboubikro forest, including 52 trees measured during the study and three plots of Ngambali forest, including 41 trees. The total number of trees measured in this study for the study sites was 93 trees (Figure 3). The 93 trees in study area are the trees with $\mathrm{DBH} \geq 10 \mathrm{~cm}$ as mentioned by Fayolle et al. (2013). However, for the distribution of trees by diameter class, we recorded in Iboubikro and Ngambali forests: 51 trees for the diameter class $10-30 \mathrm{~cm}, 36$ trees for the diameter class $30-60 \mathrm{~cm}$ and 6 trees for the diameter class $>60 \mathrm{~cm}$. We obtained the high number of trees in the diameter class $10-30 \mathrm{~cm}$ which was precisely in Plot 3 with 16 trees recorded. Total number of tree 


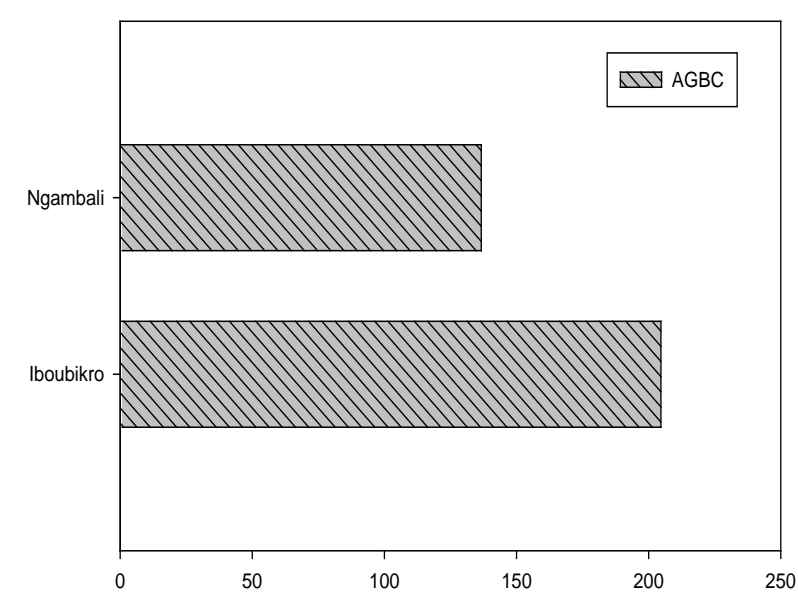

Figure 1. Average of carbon stock of above-ground biomass in Ngambali forest and Iboubikro forest ( $\left.\mathrm{C} \mathrm{ha}^{-1}\right)$.

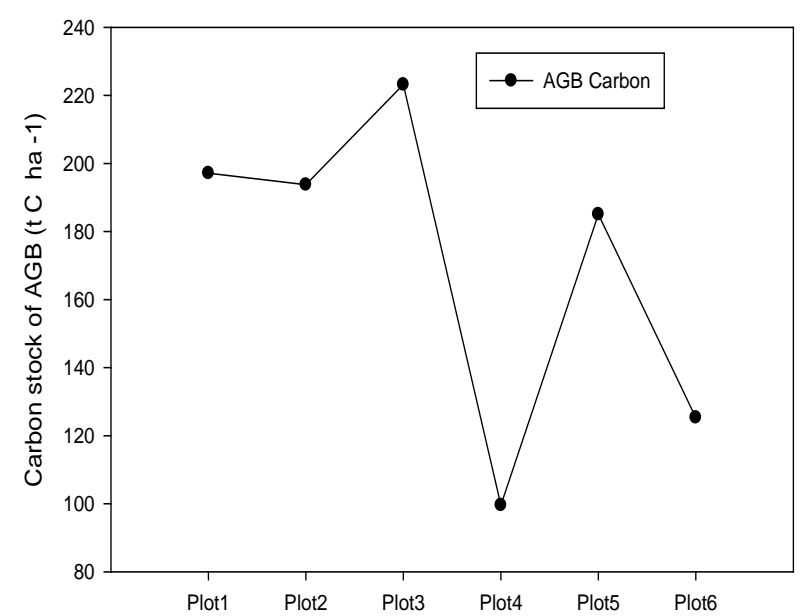

Figure 2. Carbon stock of aboveground biomass in six plots of study area (t C ha ${ }^{-1}$ ).

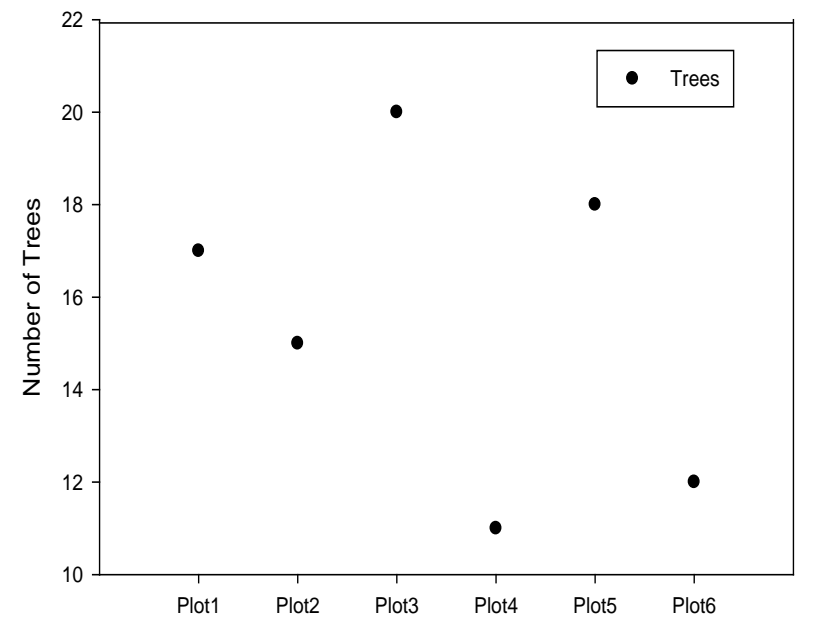

Figure 3. Total number of trees recorded in six plots studied (Iboubikro and Ngambali). 
in Plot 3 was 20 (Table 1). The average of carbon stock about above-ground biomass (AGB) in the study area was $170.6726667\left(\mathrm{t} \mathrm{C} \mathrm{ha}^{-1}\right)$.

The study was conducted in six plots, which are divided into two study sites (Iboubikro and Ngambali). Iboubikro and Ngambali forests are the galleries forests in Lesio-louna protect area of Congo. However, our study area is fed by two streams (Lesio and Ngambali). Iboubikro site is crossed by the Lesio stream that flows into the Louna stream. On the other hand, Ngambali stream running through our study Ngambali site to throw in the Blue Lake. Blue Lake empties into Louna stream. Thereafter, the stream Louna receives Lesio and Blue Lake's waters, flows into the Lefini River, then Lefini River flows into the Congo River and the Congo River flows into the Atlantic Ocean. About distribution of trees by diameter class (six plots recorded), we observed in this forest studied: 51 trees for the diameter class $10-30 \mathrm{~cm}, 36$ trees for the diameter class $30-60 \mathrm{~cm}$ and 6 trees for the diameter class $>60 \mathrm{~cm}$ (Table 1). We obtained the high number of trees in the diameter class $10-30 \mathrm{~cm}$ which was precisely in Plot 3 (20 trees). Table 1 show that the diameter class $10-30 \mathrm{~cm}$ has a high number of trees which was 51 trees, followed by diameter class $30-60 \mathrm{~cm}$ with 36 trees and diameter class $>60 \mathrm{~cm}$ with 6 trees. In six plots of the study area (Iboubikro and Ngambali forests), the Plot 3 has the highest number of trees (20 trees), followed by Plot 5 (18 trees) and Plot 1 with 17 trees. This gallery forest (Iboubikro and Ngambali sites) has 93 species recorded during this study from August to October 2012. Six plots studied contain a total of 93 trees, including 52 trees recorded in the Iboubikro site and 41 trees recorded in Ngambali site (Figure 3). In 6 plots studied, the large number of trees was recorded in Plot 3 (20 trees), followed by Plot 5 (18 trees), then the Plot 1 (17 trees). A small number of trees have been recorded in Plot 4 (11 trees). All six plots were in circular plots that the size was $1256 \mathrm{~m}^{2}$ for each (Table 2). Each plot consists of three circular radiuses (radius of $6 \mathrm{~m}$ for trees $10-30 \mathrm{~cm} \mathrm{DBH}$; radius of $14 \mathrm{~m}$ for trees $30-60 \mathrm{~cm}$ DBH and radius of $20 \mathrm{~m}$ for trees $>60 \mathrm{~cm} \mathrm{DBH})$. In Plot 5 and Plot 6, the diameter at breast height (DBH) was higher compared to Plot 1, Plot 2, Plot 3 and Plot 4 (Table 2). Plot 5 and Plot 6 are in a wet area, specifically in the Ngambali forest. Forcons, Plot 1, Plot 2, Plot 3 and Plot 4 are in an area that has as table ecosystem (the under growth is airy and litter is thick).

Figure 2 shows that the average of carbon stock for above-ground carbon (AGB) in six plots of Iboubikro and Ngambali was $170.6726667\left(\mathrm{t} \mathrm{C} \mathrm{ha}{ }^{-1}\right.$ ). The stocks of carbon about Above-ground biomass (AGB) in Iboubikro forest was $204.693\left(\mathrm{t} \mathrm{C} \mathrm{ha}^{-1}\right.$ ) and carbon stock for above ground (AGB) in Ngambali forest was 136.6523333 $\left(\mathrm{tC} \mathrm{ha}{ }^{-1}\right)$. Figure 2 shows that in this study, high quantity of carbon was obtained in Plot $3\left(223.192 \mathrm{t} \mathrm{C} \mathrm{ha}^{-1}\right.$ ), followed by Plot $1\left(197.147 \mathrm{t} \mathrm{C} \mathrm{ha}^{-1}\right)$, then Plot $2\left(193.74 \mathrm{t} \mathrm{C} \mathrm{ha}^{-1}\right)$. The small quantity of carbon was stored in the Plot 4 (99.574 t C ha-1). The area state of Plot 5 and Plot 6 in Ngambali forest is a swamp with high percent of

Table 1. Distribution of trees in study area by diameter class.

\begin{tabular}{ccccc}
\hline Plot & NTC $^{*}$ & NTC $^{* *}$ & NTC $^{* * *}$ & T \\
\hline Plot 1 & 11 & 6 & 0 & 17 \\
Plot 2 & 9 & 6 & 0 & 15 \\
Plot 3 & 16 & 4 & 0 & 20 \\
Plot 4 & 4 & 7 & 0 & 11 \\
Plot 5 & 4 & 10 & 4 & 18 \\
Plot 6 & 7 & 3 & 2 & 12 \\
Total & 51 & 36 & 6 & 93 \\
\hline
\end{tabular}

T: Total of trees; NTC*: Number of trees with diameter class $10-30 \mathrm{~cm}$ of DBH; NTC**: Number of trees with diameter class $30-60 \mathrm{~cm}$ of DBH; $\mathrm{NTC}^{* * *}$ : Number of trees with diameter class $>60 \mathrm{~cm}$ of DBH.

Table 2. Structuring of study area and distribution of carbon stocks.

\begin{tabular}{|c|c|c|c|c|c|c|}
\hline Plot & Forest Type & $\mathrm{AGBC}^{*}$ & Nest Area ${ }^{* *}$ & Site & Average $\mathrm{DBH}^{* * *}$ & State of Area \\
\hline Plot1 & Gallery forest & 197.147 & 1256 & Iboubikro & 28.82 & Normal \\
\hline Plot2 & Gallery forest & 193.740 & 1256 & Iboubikro & 30.84 & Normal \\
\hline Plot3 & Gallery forest & 223.192 & 1256 & Iboubikro & 24.56 & Normal \\
\hline Plot4 & Gallery forest & 99.574 & 1256 & Ngambali & 31.86 & Normal \\
\hline Plot5 & Gallery forest & 185.078 & 1256 & Ngambali & 40.17 & Swamp \\
\hline Plot6 & Gallery forest & 125.305 & 1256 & Ngambali & 34.44 & Swamp \\
\hline
\end{tabular}

${ }^{*}$ : Carbon stock of Above-ground biomass $\left(\mathrm{t} \mathrm{C} \mathrm{ha}{ }^{-1}\right),{ }^{* *}$ : Nest area $\left(\mathrm{m}^{2}\right),{ }^{* * *}$ : Diameter at Breast Height (cm). 
humidity in the soil. Also, there are many Millettia laurentii in this forest that is characterized by growth and development of spectacular as reported by Makany, (1976). Trees in full bloom (Millettia laurentii) attract attention because they possess purplish blue flowers. Table 2 shows that, the state area of Plot 1, Plot 2, Plot 3 and Plot 4 is normal because Plot 1, Plot 2, Plot 3 and Plot 4 are in an ecosystem that has not under gone a disturbance of human action. Also, the environment is nothumid and there's a biological balance of the ecosystems. It there's a good functioning of ecosystems in these plots in Lesio-louna forest. Table 2 shows that, the state area of Plot 5 and Plot 6 in Ngambali site (gallery forest) is swamp. Plot 5 and Plot 6 are in a swampy area. However, this study shows that, the state of plot does not influence the amount of carbon of said plot. But it is especially the nature of the species of the plot, which influences the quantity or stock of carbon. The roots of the trees of Fabaceae family have swellings called nodules that contain nitrogen-fixing bacteria as reported by Fayolle et al. (2013). There are 52 species recorded in Iboubikro site during the study and 41 species recorded in Ngambali site of Lesio-louna (Table 3). The total number of trees recorded in the study area was 93 species (Table 3). However, from a functional point of view, given the significant differences in carbon stocks, Lesio-louna forest could play an important role in carbon sequestration and could be a carbon sink on all Teke trays, even as across the Central African forest basin (Congo Basin), since different authors have observed the phenomenon of forest growth. Forest growth on savannas Lesio-louna is a fact, because the carbon stocks in biomass of this forest reserve are more than important in above-ground biomass (AGB) compared to below-ground biomass (BGB). In this gallery forest (Ngambali and Iboubikro), there are observation of the progress of the forest to savanna as reported by Makany, (1976).

Kearsley et al. (2013) about Conventional tree height-diameter relationships significantly overestimate aboveground carbon stocks in the Central Congo Basin find an average aboveground carbon stock of $162 \pm 20 \mathrm{mg}$ $\mathrm{C} \mathrm{ha}{ }^{-1}$ for intact old-growth forest, which is significantly lower than stocks recorded in the outer regions of the Congo Basin. The best available tree height-diameter relationships derived for Central Africa do not render accurate canopy height estimates for our study area. Aboveground carbon stocks would be overestimated by $24 \%$ if these inaccurate relationships were used. The studied forests have a lower stature compared with forests in the outer regions of the basin, which confirms remotely sensed patterns. Relatively few studies to date have quantified the measurement error or model uncertainty associated with the estimates of forest biomass. In one of the comprehensive studies, Chave et al. (2005) assessed the effects of measurement error (stem diameter), model uncertainty associated with height-diameter relationships, and sampling uncertainty on estimates of tropical carbon stock in Panama. They reported that the uncertainty (standard deviation) in the aboveground biomass for individual trees averaged $47 \%$ of the estimate, with $31 \%$ arising from uncertainty in the allometric model and $16 \%$ from measurement error. At the stand level, however, the effect of measurement error was reduced to less than $1 \%$, and the total uncertainty reduced to $10 \%$ due to allometric uncertainty and $10 \%$ due to sampling uncertainty. In another study, Djomo et al. (2010) propagated uncertainty in carbon stock estimates in tropical forest in Cameroon using the statistical propagation techniques described in Chave et al. (2005), and reported that uncertainty in allometric equations contributed $30 \%$ of the total uncertainty in carbon stock estimates. These estimates may have overestimated the uncertainty due to allometric models. Another limitation of these studies is that they have focused on tropical forests. Previous studies have tended to focus on uncertainty in carbon stock estimates, rather than uncertainty in carbon change over time. Carbon change is arguably the more important of the two metrics as it is the basis for United Nations Framework Convention on Climate Change (UNFCCC) reporting, including programs such as REDD+ (Pelletier et al. 2012). We expected that model uncertainty is likely to be less important for carbon change estimates provided that the same allometric equations are used to calculate carbon stocks at both time periods.

\section{Conclusion}

The study shows that, the carbon stock in a forest ecosystem is not necessarily influenced by the number of trees of this forest ecosystem. Diameter at breast height (DBH) of a tree is not necessarily related to the carbon stock of the tree, as we have seen in some high diameter at breast height (DBH) trees, but with a low carbon stock. We also recorded some trees with low diameter at breast height (DBH), but with a significant stock of carbon. This research has helped us to understand that in these two gallery forests, Iboubikro forest has a higher carbon stock compared to Ngambali forest. In general, Iboubikro and Ngambali forests of Congo have a higher carbon stock and can participate effectively in mitigating of global climate change. 
Table 3. Distribution of species by family in six plots of study area.

\begin{tabular}{|c|c|c|c|c|}
\hline Species & Family & Forest Type & Plot & DBH (in cm) \\
\hline Allophylus africanus & Sapindaceae & Gallery forest & Plot2 & 25.6 \\
\hline Allophylus africanus & Sapindaceae & Gallery forest & Plot3 & 27.5 \\
\hline Allophylus africanus & Sapindaceae & Gallery forest & Plot5 & 71.1 \\
\hline Allophylus africanus & Sapindaceae & Gallery forest & Plot5 & 30.6 \\
\hline Allophylus africanus & Sapindaceae & Gallery forest & Plot5 & 46.7 \\
\hline Allophylus africanus & Sapindaceae & Gallery forest & Plot6 & 43.3 \\
\hline Barteria fistulosa & Passifloraceae & Gallery forest & Plot1 & 19.6 \\
\hline Barteria fistulosa & Passifloraceae & Gallery forest & Plot1 & 14.6 \\
\hline Barteria fistulosa & Passifloraceae & Gallery forest & Plot1 & 21.2 \\
\hline Berlinia bracteosa & Annonaceae & Gallery forest & Plot4 & 50.6 \\
\hline Colletoecema dewevrei & Rubiaceae & Gallery forest & Plot6 & 19.1 \\
\hline Colletoecema dewevrei & Rubiaceae & Gallery forest & Plot6 & 23.6 \\
\hline Dacryodes buettneri & Burseraceae & Gallery forest & Plot1 & 24.3 \\
\hline Dacryodes buettneri & Burseraceae & Gallery forest & Plot3 & 22.2 \\
\hline Eriocoelum macrocarpum & Sapindaceae & Gallery forest & Plot1 & 25.9 \\
\hline Eriocoelum macrocarpum & Sapindaceae & Gallery forest & Plot2 & 25.3 \\
\hline Eriocoelum macrocarpum & Sapindaceae & Gallery forest & Plot3 & 13.5 \\
\hline Eriocoelum macrocarpum & Sapindaceae & Gallery forest & Plot3 & 22.6 \\
\hline Eriocoelum macrocarpum & Sapindaceae & Gallery forest & Plot3 & 20.3 \\
\hline Eriocoelum macrocarpum & Sapindaceae & Gallery forest & Plot3 & 22.2 \\
\hline Eriocoelum macrocarpum & Sapindaceae & Gallery forest & Plot5 & 63.8 \\
\hline Eriocoelum macrocarpum & Sapindaceae & Gallery forest & Plot5 & 40.0 \\
\hline Eriocoelum spp. & Sapindaceae & Gallery forest & Plot2 & 41.1 \\
\hline Eriocoelum spp. & Sapindaceae & Gallery forest & Plot5 & 44.3 \\
\hline Ficus deltoidea & Moraceae & Gallery forest & Plot4 & 30.4 \\
\hline Ficus deltoidea & Moraceae & Gallery forest & Plot4 & 34.0 \\
\hline Ficus deltoidea & Moraceae & Gallery forest & Plot4 & 38.7 \\
\hline Ficus spp. & Moraceae & Gallery forest & Plot4 & 31.1 \\
\hline Hymenocardia spp. & Hymenocardiaceae & Gallery forest & Plot3 & 28.5 \\
\hline Hymenocardia spp. & Hymenocardiaceae & Gallery forest & Plot5 & 41.6 \\
\hline Hymenocardia spp. & Hymenocardiaceae & Gallery forest & Plot5 & 33.8 \\
\hline Hymenocardia ulmoides & Hymenocardiaceae & Gallery forest & Plot1 & 16.9 \\
\hline Hymenocardia ulmoides & Hymenocardiaceae & Gallery forest & Plot1 & 50.3 \\
\hline Hymenocardia ulmoides & Hymenocardiaceae & Gallery forest & Plot3 & 20.4 \\
\hline Hymenocardia ulmoides & Hymenocardiaceae & Gallery forest & Plot3 & 29.6 \\
\hline Indeterminate 1 & Fabaceae & Gallery forest & Plot1 & 25.5 \\
\hline Indeterminate2 & Sapotaceae & Gallery forest & Plot2 & 15.4 \\
\hline Indeterminate3 & Sapotaceae & Gallery forest & Plot2 & 10.6 \\
\hline Millettia laurentii & Fabaceae & Gallery forest & Plot1 & 33.2 \\
\hline Millettia laurentii & Fabaceae & Gallery forest & Plot1 & 56.4 \\
\hline Millettia laurentii & Fabaceae & Gallery forest & Plot2 & 24.4 \\
\hline Millettia laurentii & Fabaceae & Gallery forest & Plot2 & 34.4 \\
\hline Millettia laurentii & Fabaceae & Gallery forest & Plot2 & 55.9 \\
\hline Millettia laurentii & Fabaceae & Gallery forest & Plot5 & 51.5 \\
\hline Millettia laurentii & Fabaceae & Gallery forest & Plot5 & 30.1 \\
\hline Millettia laurentii & Fabaceae & Gallery forest & Plot5 & 34.8 \\
\hline Millettia laurentii & Fabaceae & Gallery forest & Plot6 & 38.8 \\
\hline
\end{tabular}




\section{Continued}

\begin{tabular}{|c|c|c|c|c|}
\hline Millettia laurentii & Fabaceae & Gallery forest & Plot6 & 43.4 \\
\hline Millettia laurentii & Fabaceae & Gallery forest & Plot6 & 11.5 \\
\hline Millettia pinnata & Fabaceae & Gallery forest & Plot3 & 36.4 \\
\hline Mitragyna stipulosa & Rubiaceae & Gallery forest & Plot6 & 23.4 \\
\hline Mitragyna stipulosa & Rubiaceae & Gallery forest & Plot6 & 14.1 \\
\hline Musanga cecropioides & Urticaceae & Gallery forest & Plot2 & 35.2 \\
\hline Musanga cecropioides & Urticaceae & Gallery forest & Plot5 & 10.1 \\
\hline Musanga cecropioides & Urticaceae & Gallery forest & Plot5 & 17.2 \\
\hline Omphalocarpum elatum & Sapotaceae & Gallery forest & Plot1 & 27.8 \\
\hline Omphalocarpum elatum & Sapotaceae & Gallery forest & Plot3 & 33.4 \\
\hline Omphalocarpum elatum & Sapotaceae & Gallery forest & Plot3 & 34.2 \\
\hline Pancovia laurentii & Sapindaceae & Gallery forest & Plot4 & 17.4 \\
\hline Pentaclethra eetveldeana & Mimosaceae & Gallery forest & Plot1 & 30.1 \\
\hline Pentaclethra spp. & Mimosaceae & Gallery forest & Plot4 & 49.8 \\
\hline Pentaclithra eetveldeana & Mimosaceae & Gallery forest & Plot1 & 33.1 \\
\hline Pentaclithra eetveldeana & Mimosaceae & Gallery forest & Plot1 & 55.6 \\
\hline Pentaclithra eetveldeana & Mimosaceae & Gallery forest & Plot2 & 28.3 \\
\hline Pentaclithra eetveldeana & Mimosaceae & Gallery forest & Plot2 & 28.9 \\
\hline Pentaclithra eetveldeana & Mimosaceae & Gallery forest & Plot2 & 59.2 \\
\hline Pentaclithra eetveldeana & Mimosaceae & Gallery forest & Plot2 & 53.8 \\
\hline Pentaclithra eetveldeana & Mimosaceae & Gallery forest & Plot3 & 15.5 \\
\hline Pentaclithra eetveldeana & Mimosaceae & Gallery forest & Plot3 & 10.9 \\
\hline Pentaclithra eetveldeana & Mimosaceae & Gallery forest & Plot3 & 25.3 \\
\hline Piptadeniastrum africanum & Mimosaceae & Gallery forest & Plot3 & 22.8 \\
\hline Piptadeniastrum africanum & Mimosaceae & Gallery forest & Plot4 & 58.8 \\
\hline Piptadeniastrum africanum & Mimosaceae & Gallery forest & Plot5 & 85.0 \\
\hline Piptadeniastrum africanum & Mimosaceae & Gallery forest & Plot6 & 68.0 \\
\hline Piptadeniastrum africanum & Mimosaceae & Gallery forest & Plot6 & 75.8 \\
\hline Sorindeia juglandifolia & Anacardiaceae & Gallery forest & Plot1 & 19.3 \\
\hline Sorindeia juglandifolia & Anacardiaceae & Gallery forest & Plot1 & 13.8 \\
\hline Sorindeia juglandifolia & Anacardiaceae & Gallery forest & Plot1 & 22.5 \\
\hline Sorindeia juglandifolia & Anacardiaceae & Gallery forest & Plot2 & 12.9 \\
\hline Sorindeia juglandifolia & Anacardiaceae & Gallery forest & Plot3 & 26.5 \\
\hline Symphonia globulifera & Clusiaceae & Gallery forest & Plot4 & 12.8 \\
\hline Symphonia globulifera & Clusiaceae & Gallery forest & Plot4 & 11.0 \\
\hline Symphonia globulifera & Clusiaceae & Gallery forest & Plot5 & 11.0 \\
\hline Symphonia globulifera & Clusiaceae & Gallery forest & Plot5 & 15.8 \\
\hline Symphonia globulifera & Clusiaceae & Gallery forest & Plot5 & 31.5 \\
\hline Symphonia spp. & Clusiaceae & Gallery forest & Plot4 & 15.9 \\
\hline Symphonia spp. & Clusiaceae & Gallery forest & Plot6 & 18.4 \\
\hline Uapaca heudelotii & Euphorbiaceae & Gallery forest & Plot5 & 64.2 \\
\hline Xylopia aethiopica & Annonaceae & Gallery forest & Plot2 & 11.6 \\
\hline Xylopia rubescens & Annonaceae & Gallery forest & Plot6 & 33.9 \\
\hline Xylopia rubescens & Annonaceae & Gallery forest & Plot3 & 36.6 \\
\hline Xylopia rubescens & Annonaceae & Gallery forest & Plot3 & 22.5 \\
\hline Xylopia rubescens & Annonaceae & Gallery forest & Plot3 & 20.3 \\
\hline
\end{tabular}




\section{Acknowledgements}

The authors grateful acknowledge Chinese and Congolese governments by China Scholarship Council (CSC), Beijing Forestry University, Université Marien Ngouabi, MDDEFE-REDD+/WRI Project and Lesio-louna Project for supporting this research.

\section{References}

Alvarez, E., Duque, A., Saldarriaga, J., Cabrera, K., De las Salas, G., Del Valle, I., Lema A., Moreno, F., Orrego, S., \& Rodríguez, L. (2012). Tree Above-Ground Biomass Allometries for Carbon Stocks Estimation in the Natural Forests of Colombia. Forest Ecology and Management, 267, 297-308. http://dx.doi.org/10.1016/j.foreco.2011.12.013

ANAC (2014). Situation Météorologique Nationale. Rapport annuel de l'agence nationale de l'aviation civile (ANAC), Ministère de transport et de l'aviation civile (Republic of Congo), Brazzaville, 5-82.

Anon (2010). Rapport annuel du projet Lesio-louna, the Aspinall Foundation. Ministère de Développement Durable, de l’Economie Forestière et de l'Environnement, Brazzaville, 10-55.

Brown, S. (2002). Measuring Carbon in Forests: Current Status and Future Challenges. Environmental Pollution, 116, 363372. http://dx.doi.org/10.1016/S0269-7491(01)00212-3

Brown, S., Burnham, M., Delaney, M., Vaca, R., Powell, M., \& Moreno, A. (2000). Issues and Challenges for Forest-Based Carbon-Offset Projects: A Case Study of the Noel Kempff Climate Action Project in Bolivia. Mitigation and Adaptation Strategies for Climate Change, 5, 99-121. http://dx.doi.org/10.1023/A:1009620903231

Brown, S., Pearson, T., Slaymaker, D., Ambagis, S., Moore, N., Novelo, D., \& Sabido, W. (2004). Application of Multispectral 3-Dimensional Aerial Digital Imagery for Estimating Carbon Stocks in a Tropical Pine Savanna. Report to the Nature Conservancy Conservation Partnership Agreement, 12-22.

Chave, J., Andalo, C., Brown, S., Cairns, M. A., Chambers, J. Q., Eamus, D., Fölster, H., Fromard, F., Higuchi, N., Kira, T., Lescure, J. P., Nelson, B. W., Ogawa, H., Puig, H., Riera, B., \& Yamakura, T. (2005). Tree Allometry and Improved Estimation of Carbon Stocks and Balance in Tropical Forests. Oecologia, 145, 87-99. http://dx.doi.org/10.1007/s00442-005-0100-x

Chave, J., Condit, R., Muller-Landau, H., Thomas, S., Ashton, P., Bunyavejchewin, S., Co, L., Dattaraja, H., Davies, S., Esufali, S., Ewango, C., Feeley, K., Foster, R., Gunatilleke, N., Gunatilleke, S., Hall, P., Hart, T., Hernández, C., Hubbell, S., Itoh, A., Iratiprayoon, S., Lafrankie, J., Loo de Lao, S., Makana, J., Noor, N., Kassim, A., Samper, C., Sukumar, R., Suresh, H., Tan, S., Thompson, J., Tongco, M., Valencia, R., Vallejo, M., Villa, G., Yamakura, T., Zimmerman, J., \& Losos, E. (2008). Assessing Evidence for a Pervasive Alteration in Tropical Tree Communities. Plos Biology, 6, e45. http://dx.doi.org/10.1371/journal.pbio.0060045

Chave, J., Riéra, B., \& Dubois, M. (2001). Estimation of Biomass in a Neotropical Forest of French Guiana: Spatial and Temporal Variability. Journal of Tropical Ecology, 17, 79-96. http://dx.doi.org/10.1017/S0266467401001055

Djomo, N. A., Ibrahima, A., Saborowski, J., \& Gravenhorst, G. (2010). Allometric Equations for Biomass Estimations in Cameroon and Pan Moist Tropical Equations Including Biomass Data from Africa. Forest Ecology and Management, 260, 1873-1885. http://dx.doi.org/10.1016/j.foreco.2010.08.034

Ekoungoulou, R., Liu, X., Ifo, S. A., Loumeto, J. J., \& Folega, F. (2014a). Carbon Stock Estimation in Secondary Forest and Gallery Forest of Congo Using Allometric Equations. International Journal of Scientific \& Technology Research, 3, 465474.

Ekoungoulou, R., Liu, X., Loumeto, J. J., \& Ifo, S. A. (2014b). Tree Above- and Below-Ground Biomass Allometries for Carbon Stocks Estimation in Secondary Forest of Congo. Journal of Environmental Science, Toxicology and Food Technology, 8, 9-20. http://dx.doi.org/10.9790/2402-08420920

FAO (2008). Les forêts du Bassin du Congo, Etat des Forêts. Rome: Organisation des Nations Unies pour l'Alimentation et l'Agriculture (UNFAO), 50-60.

FAO (2011). Situation des forets du monde. Rome: Organisation des Nations Unies pour l'Alimentation et l'Agriculture, 102-177.

Fayolle, A., Doucet, J. L., Gillet, J. F., Bourland, N., \& Lejeune, P. (2013). Tree Allometry in Central Africa: Testing the Validity of Pantropical Multi-Species Allometric Equations for Estimating Biomass and Carbon Stocks. Forest Ecology and Management, 305, 29-37. http://dx.doi.org/10.1016/j.foreco.2013.05.036

Gorte, W. R. (2009). Carbon Sequestration in Forests. Congressional Research Service, Natural Resources Policy, Report for Congress, 2-20. WwW.crs.govRL31432

Hall, A. (2012). Forests and Climate Change. The Social Dimensions of REDD in Latin America, 201- 213.

Holdaway, J. R., McNeill, S. J., Mason, N. W. H., \& Carswell, F. E. (2014). Propagating Uncertainty in Plot-Based Esti- 
mates of Forest Carbon Stock and Carbon Stock Change. Ecosystems, 17, 627-640.

IPCC (2001). IPCC Third Assessment Report. Climate Change 2001: The Scientific Basis. Contribution of Working Group 1 to the Third Assessment Report of the Intergovernmental Panel on Climate Change. Cambridge: Cambridge University Press, 800-881.

IPCC (2011). Renewable Energy Sources and Climate Change Mitigation. Special Report of the Intergovernmental Panel on Climate Change (IPCC), Summary for Policymakers and Technical Summary, WMO, UNEP, 220-246.

Kearsley, E., Haulleville, T. D., Hufkens, K., Kidimbu, A., Toirambe, B., Baert, G., Huygens, D., Kebede, Y., Defourny, P., Bogaert, J., Beeckman, H., Steppe, K., Boeckx, P., \& Verbeeck, H. (2013). Conventional Tree Height-Diameter Relationships Significantly Overestimate Aboveground Carbon Stocks in the Central Congo Basin. Nature Communications, 4, 18.

Killeen, T. J., Siles, T. M., Grimwood, T., Tieszen, L. L., Steininger, M. K., Tucker, C. J., \& Panfil, S. (2002). Habitat Heterogeneity on a Forest-Savanna Ecotone in Noel Kempff Mercado National Park (Santa Cruz, Bolivia): Implications for the Long-Term Conservation of Biodiversity in a Changing Climate. In G. A. Bradshaw, \& P. A. Marquet (Eds.), How Landscapes Change: Human Disturbance and Ecosystem Fragmentation in the America. Heidelberg: Springer-Verlag, 285312.

Lewis, S. L., Lopez-Gonzalez, G., Sonke, B., Affum-Baffoe, K., Baker, T. R., Ojo, L. O., Phillips, O. L., Reitsma, J. M., White, L., Comiskey, J. A., Djuikouo, K. M. N., Ewango, C. E. N., Feldpausch, T. R., Hamilton, A. C., Gloor, M., Hart, T., Hladik, A., Lloyd, J., Lovett, J. C., Makana, J. R., Malhi, Y., Mbago, F. M., Ndangalasi, H. J., Peacock , J., Peh, K. S. H., Sheil, D., Sunderland, T., Swaine, M. D., Taplin, J., Taylor, D., Thomas, S. C., Votere, R., \& Woll, H. (2009). Increasing Carbon Storage in Intact African tropical forests. Nature, 457, 1003-1006. http://dx.doi.org/10.1038/nature07771

Makany, L. (1976). Végétation des Plateaux Teke, Travaux Universitaires. Brazzaville: Université Marien Ngouabi, $254-301$.

Malhi, Y., Baker, T. R., Phillips, O. L., Almeida, S., Alvarez, E., Arroyo, L., Chave, J., Czimczik, C. I., Di-Fiore, A., Higuchi, N., Killeen, T. J., Laurance, S. G., Laurance, W. F., Lewis, S. L., Montoya, L. M. M., Monteagudo, A., Neill, D. A., Nunez-Vargas, P., Patin, O. S., Pitman, N. T., Vasques-Martinez, R., Terborgh, J., Vinceti, B., \& Lloyd, J. (2004). The Above-Ground Coarse Wood Productivity of 104 Neotropical Forest Plots. Global Change Biology, 10, 563-591. http://dx.doi.org/10.1111/j.1529-8817.2003.00778.x

Pearson, T., \& Brown, S. (2005). Guide de mesure et de suivi du carbone dans les forêts et prairies herbeuses. Winrock International, 11-35.

Pelletier, J., Kirby, K. R., \& Potvin, C. (2012). Significance of Carbon Stock Uncertainties on Emission Reductions from Deforestation and Forest Degradation in Developing Countries. Forest Policy and Economics, 24, 3-11.

Phillips, O. L, Malhi, Y., Higuchi, N., Laurance, W. F., Nunez, P. V., Vasquez, R. M., Laurance, S. G., Ferreira, L. V., Stern, M., Brown, S., \& Grace, J. (1998). Changes in the Carbon Balance of Tropical Forests: Evidence from Long-Term Plots. Science, 282, 439-442. http://dx.doi.org/10.1126/science.282.5388.439

Saatchi, S. S., Harris, N. L., Brown, S., Lefsky, M., Mitchard, E. T. A., Salas, W., Zutta, B. R., Buermann, W., Lewis, S. L., Hagen, S., Petrova, S., White, L., Silman, M., \& Morel, A. (2011). Benchmark Map of Forest Carbon Stock in Tropical Regions across Three Continents. PNAS Early Edition, Environmental Sciences. Irvine, CA: University of California, 1-6.

White, J. G., Southgate, E., Thomson, J. N., \& Brenner, S. (1986). The Structure of the Nervous System of the Nematode Caenorhabditis Elegans. Philosophical Transactions of the Royal Society B: Biological Sciences, 314, 305-340. http://dx.doi.org/10.1098/rstb.1986.0056

Yanai, R., Battles, J., Richardson, A., Blodgett, C., Wood, D., \& Rastetter, E. (2010). Estimating Uncertainty in Ecosystem Budget Calculations. Ecosystems, 13, 239-248. http://dx.doi.org/10.1007/s10021-010-9315-8

Zhang, Q., Justice, C. O., \& Desanker, P. V. (2002). Impacts of Simulated Shifting Cultivation on Deforestation and the Carbon Stocks of the Forests of Central Africa. Agriculture, Ecosystems \& Environment, 90, 203-209. http://dx.doi.org/10.1016/S0167-8809(01)00332-2 
Scientific Research Publishing (SCIRP) is one of the largest Open Access journal publishers. It is currently publishing more than 200 open access, online, peer-reviewed journals covering a wide range of academic disciplines. SCIRP serves the worldwide academic communities and contributes to the progress and application of science with its publication.

Other selected journals from SCIRP are listed as below. Submit your manuscript to us via either submit@scirp.org or Online Submission Portal.
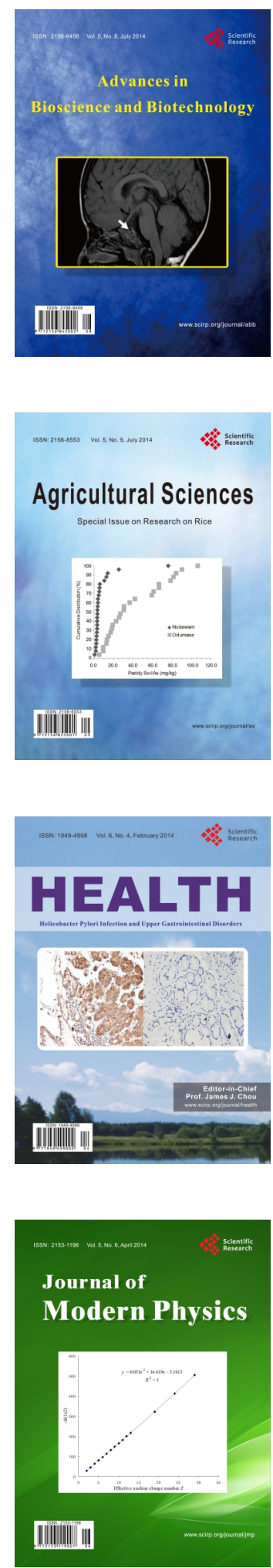
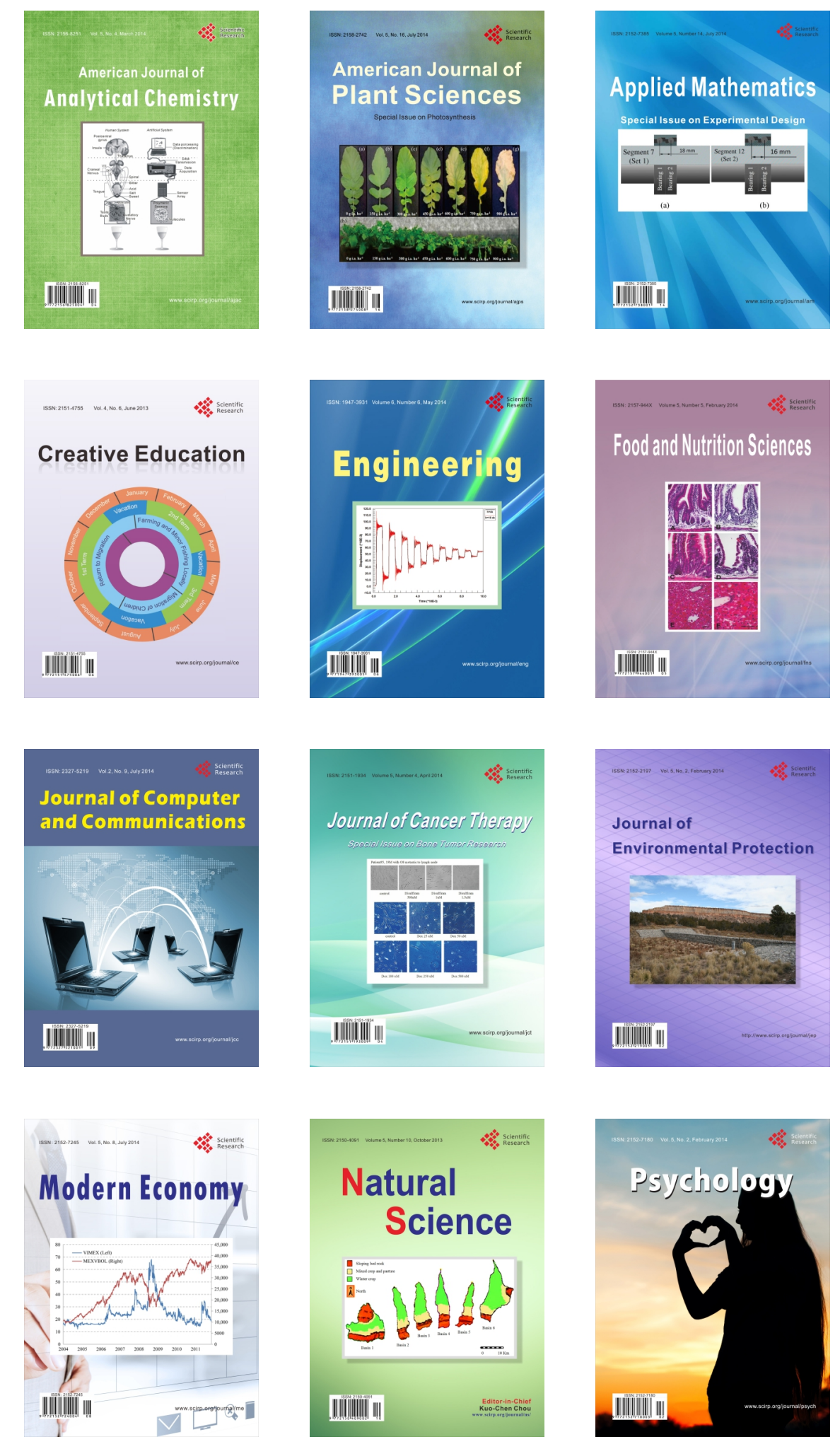